\title{
EVIDENCE OF CONTAMINATION BY OIL AND OIL PRODUCTS IN THE SANTOS-SÃO VICENTE ESTUARY, SÃO PAULO, BRAZIL
}

\author{
Juliana Souza Azevedo ${ }^{1,2}$, Belisandra Lopes ${ }^{4}$, Alberto Katsumiti ${ }^{3}$, \\ Elisabete Santis Braga ${ }^{2}$, Helené Roche ${ }^{5}$, Ciro Alberto Oliveira Ribeiro ${ }^{3}$ and Maria João Bebianno ${ }^{4}$ \\ ${ }^{1}$ Instituto de Pesquisas Energéticas e Nucleares, Centro de Química e Meio Ambiente \\ (Av. Prof. Lineu Prestes, 2242, 05508-900 São Paulo, SP, Brasil) \\ ${ }^{2}$ Instituto Oceanográfico da Universidade de São Paulo \\ (Praça do Oceanográfico, 191, 05508-120 São Paulo, SP, Brasil) \\ ${ }^{3}$ Universidade Federal do Paraná, Departamento Biologia Celular \\ (Caixa-Postal: 19031, 81531-990 Curitiba, PR, Brasil) \\ ${ }^{4}$ Universidade do Algarve, Centro de Investigação Marinha e do Ambiente \\ (Campus de Gambelas, 8005-139 Faro, Portugal) \\ ${ }^{5}$ Université Paris-Sud XI, Ecologie Systématique et Evolution \\ (Bâtiment, 362 F91405, Orsay, Cedex, France) \\ *Corresponding author: juliana_azevedo@msn.com
}

\begin{abstract}
A B S TR A C T
Different components of the mixed function oxidase (MFO) system and the levels of fluorescent aromatic compounds in bile (FACs) were measured in Cathorops spixii in order to assess the impact of polycyclic aromatic hydrocarbons (PAHs). Fish were sampled in an estuary (Santos/São Vicente) with a history of contamination by PAHs, mainly due to the presence of the industrial complex of Cubatão city and of another of low anthropogenic influence (Cananéia) on the Brazilian coast. FACs were higher in fish from the polluted site, and the PAH 5 and 6-ring metabolites were the most frequent - with $14 \%$ and $15 \%$, respectively. Levels of the different components of the MFO system showed the same variation profile as the FACs for both estuaries. Therefore, the values found for somatic indexes and biomarkers with data of bile PAH metabolites indicate the presence of organic contaminants, especially in the area subject to the influence of the industrial complex on the Santos/São Vicente estuary.
\end{abstract}

\section{RESUMO}

Diferentes componentes do sistema oxidase de função mista (MFO) e os níveis de compostos aromáticos fluorescentes em bile (FACS) foram determinados em Cathorops spixii a fim de avaliar o impacto de hidrocarbonetos policíclicos aromáticos (PAHs). Os peixes foram coletados em um estuário com histórico de contaminação por PAHs (Santos/São Vicente), devido principalmente a presença do complexo industrial na cidade de Cubatão e em outro com baixa influência antropogênica (Cananéia) na costa brasileira. FACs foram maiores nos peixes oriundos da área contaminada, sendo os metabolitos de HPAs com 5 e 6 anéis, os mais representativos com 14\% e $15 \%$, respectivamente. Os níveis dos diferentes componentes do sistema MFO mostraram o mesmo perfil de variação que os FACs em ambos os estuários. Portanto, os valores encontrados para os índices somáticos e os biomarcadores considerados, em associação com os dados de metabólitos biliares de PAHs, indicam a presença de contaminantes orgânicos, principalmente na área sob influência do complexo industrial no estuário de Santos/São Vicente.

Descriptors: Fluorescent aromatic compounds, Cytochrome P450, MFO system, Cathorops spixii, Brazilian coast.

Descritores: Compostos aromáticos fluorescentes, Citocromo P450, Sistema MFO, Cathorops spixii, Costa brasileira.

\section{INTRODUCTION}

The aquatic environment is affected by human activity and mainly by industrial discharges. Estuaries, in particular, are affected by urban, industrial, harbor and sometimes agricultural discharges (OLIVEIRA RIBEIRO et al., 2005; VALDEZ DOMINGOS et al., 2007; AKAISHI et al., 2007). In aquatic ecosystems, contaminants bioaccumulation represent a potential risk to the biota and consequently to human health (HELLOU et al., 2006). The input of different pollutants in the 
environment can affect the organism and, therefore, they are exposed to a complex mixture of contaminants (BOENING, 2000).

The liver represents one of the most important organs for bioaccumulation processes and metabolic pathways in which the monooxigenases enzymes are involved. Cytochrome P450s (CYPs) are a large superfamily of heme-proteins that play key roles in the xenobiotic biotransformation and in the synthesis and degradation of physiologically important endogenous substrates (FU et al., 2011). This family of monooxygenases includes the cytochrome $b_{5}, \mathrm{NADPH}$ cit. $c$ P450 reductase and NADH cit. $b_{5}$ reductase as cofactors(SCHLENK et al. 1993; ALARABI; GOKSOYR, 2002; SCHENKMAN; JANSSON, 2003) and, the CYP450 activity depends on a variety of factors, such as age, sex, sexual maturity, seasonality, exposure history and diet (HARTL et al., 2007).

The analyses of PAH metabolites in fish bile provides information about its exposure to $\mathrm{PAH}$ compounds (VUORINEN et al., 2006). The fluorescent aromatic compounds (FACs) determinationin fish bile is very important for the environmental quality evaluationto assess the organic levels of contamination and the potential risk offered for the biota. PAHs can accumulate in fish tissues inducing the activity of several enzymes, e.g. glutathione-S-transferase (VUORINEN et al., 2006), but especially the MFO system (STAGG et al., 2000; WHYTE et al., 2000; VUORINEN et al., 2006). Intracellular biotransformation of PAHs is related to mixed function oxidase (MFO) system (SCHLENK et. al., 1993). Although there are considerable differences in PAH inducing capacity, the study of different components that integrate the MFO system shows a crucial in the PAH metabolism (WHYTE et al., 2000; VUORINEN et al., 2006). MFO system also includes: i) cytochrome $b_{5}$, a heme-protein that act as intermediate in the unsaturation of fatty acids and can also acts as electron donor to cytochrome P450; ii) the $\mathrm{NADPH}$ cit. $c \mathrm{P} 450$ reductase, a flavoprotein responsible for the electron transfer from the NADPH to cytochromes $\mathrm{P} 450$ and $b_{5}$; and iii) the NADH cit. $b_{5}$ redutase, a flavoprotein responsible for the electron transference from the NADH to cytochrome $b_{5}$. It is important to remark that the components of this system are also involved in electron transport of other $\mathrm{r}$ biological processes and in apoptosis (MEHRTENS; LATURNUS; 1999).

Fish have a high confirmed capacity to accumulate metals and organic compounds in their tissues (FISK et al., 2001). Therefore, fish are select as good bioindicators for environmental studies due to their capacity to accumulate pollutants in target tissues, transferring xenobiotics through trophic chain (FISK et al., 2001; BOON et al., 2002; OLIVEIRA
RIBEIRO et al. 2005). Furthermore, aquatic organisms are able to metabolize hydrocarbon compounds and to transform them into more polar, soluble by-products that are readily excreted. This metabolism is mediated via MFO system (SERAFIM et al., 2008).

Ariidae catfish, Cathorops spixii, commonly known as "Madamango sea catfish", has a wide geographical distribution in the Atlantic coast of South America, from Belize to the Brazilian Southeast coast, and also is the most common catfish that occurring in the Brazilian Coast (TIJARO et al., 1998). C. spixii spaws in late spring/early summer and have a total spawning with synchronic development of oocytes, and the fecundity is low when compared to other fish (GOMES et al., 1999; FÁVARO et al., 2005). C. spixii is a demersal fish species that feeds mainly the pelitic fraction (organic detritus) where the concentration of contaminants tends to be higher. Bioaccumulation and effects of organic pollutants were demonstrated in Cathorops spixii before (MAGALHÃES, 2005), but previous studies of our research group (AZEVEDO et al., 2009; AZEVEDO et al., 2009a) demonstrated that $C$. spixii is also an efficient sentinel species for trace metal contamination.

For a better comprehension of the biotransformation/bioaccumulation of organic compounds, it is necessary to support information regarding $\mathrm{PAH}$ metabolites in fish bile and evaluation of the MFO contents with biological data such as the hepatic somatic index (HSI) and condition factor (CF) to assess the toxic effects in the organism. Somatic indexes were previously used in biomonitoring studies as an efficient tool to support biomarkers responses in sentinel some species (ADAMS; RYON, 1994; AZEVEDO et al., 2009a; LOMBARD et al., 2010). The CF indicates the environmental condition for living organisms such as fish and is an useful tool to compare different populations exposed to a variety environmental stresses. According to Adams and Ryon (1994) and Karels et al. (1998), fish from polluted areas generally show lower CF values, while highest $\mathrm{CF}$ values are found in fish that reflect a larger adaptation to the environment. The HSI reflect the proportion between the liver and whole body (ZIMMERMAN, 1997) and HSI values tends to be lower in the period of gonadal maturation reflecting the use of hepatic reserves during the vitellogenesis processes (GURGEL et al., 2000). Fish from polluted environments usually show high HSI values (ADAMS; RYON, 1994; KARELS et al., 1998).

In the present study, responses of the MFO system in the benthic fish C. spixii exposed to "in situ" organic contamination were determined. Additionally, FACs in fish bile were also determined to access the PAH bioavailability in two estuaries with different anthropogenic activities located in the Brazilian coast. 
$\mathrm{CF}$ and HSI were also calculated in order to estimate the biological conditions of the individuals. As far as we know, this is the first study relating FACs and MFO system in a fish species in the southeastern Brazilian coast.

\section{Material ANd Methods}

\section{Study Area}

Santos' Bay is located in the southeastern coast of Brazil, as a part of São Paulo State seaboard $\left(24^{\circ} 00^{\prime} \mathrm{S} ; 46^{\circ} 21^{\prime} \mathrm{W}\right)$. The tropical rain forest climate is typical, with a heavy rainy season. The industrial activity and the tourism constitute important economic activities and recently marine petroleum exploitation activities are starting in this area. The largest commercial harbor of South America and one of the most important petrochemical and metallurgical industrial areas of Brazil (industrial complex of Cubatão city) are located in Baixada Santista region, constituted by approximately 1100 industries. The increase in the urbanization and industrialization close to the estuarine area, mainly in the last 50 years, was the principal responsible for the degradation of the mangrove vegetation and generated industrial impacts and also elevated the generation of domestic sewage effluents and solid wastes. Environmental programs of pollution control contributed to light diminution in the pollution impact in this area in the last few years, but the new petroleum exploitation activities could contribute to a new input of contaminants. For this reason, we consider very important the establishment of a monitoring program in this area.
Cananéia estuarine-lagoon complex, located in the southern coastal region of the São Paulo State $\left(25^{\circ} \mathrm{S} ; 48^{\circ} \mathrm{W}\right)$ was selected as reference sampling site due to their relative unpolluted waters and to their preserved estuarine ecosystem. The inner section of the estuarine-lagoon complex is subject to tidal cycles and freshwater inputs that define the regime of water circulation and water mixture in this estuarine-lagoon complex. The $C$. spixii was also present in this second system.

\section{Collection of Animals and Sampling Sites}

Fish were collected using a R/V Velliger II in winter 2005 and summer 2006 in two estuarine system at Santos/São Vicente estuarine system (San) affected by distinct contamination levels: Santos Bay (SB) $\mathrm{n}=10$; Santos Channel (SC) $\mathrm{n}=10$ and São Vicente Channel (SVC) $n=10$. From reference area (Cananéia estuarine-lagoon complex, Can) were collected 18 animals using R/V Albacora (Fig. 1). Both sampling were performed using a bottom Otter Trawl (1.6" mesh wall and 1.2" mesh cod end) with $11 \mathrm{~m}$ length, set at $8.8 \mathrm{~m}$ depth. The selection of the three sites at San system was done according the different degrees of anthropogenic influence on the aquatic system: SC site, inner part of the system, is affected by intense industrial activity; SBsite, less affected by industrial activity, at this sampling site dilution process of the chemical compounds is regulated by the marine currents; SVC site characterized by the presence of mangrove and precarious urban occupation. Can is situated into the UNESCO biosphere reserve of Iguape-Cananéia and shows an excellent conservation state (Fig. 1).

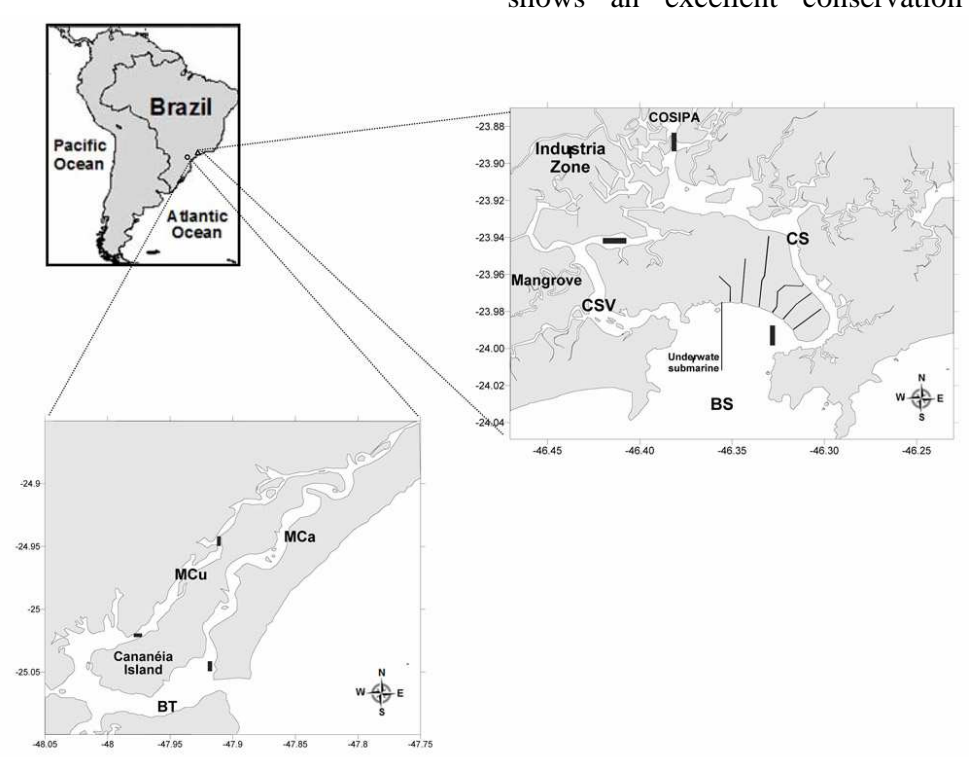

Fig. 1. Map of studied sites showing the sampling sites in Cananéia and Santos-São Vicente estuaries (Santos Bay: SB, Santos channel: SC, and São Vicente channel: SVC), São Paulo, Brazil. 
C. spixii species was identified according to Figueiredo and Menezes (1978). After collection of the animals, fishes were kept in the same water of the sampling site and transported to the laboratory. The individuals were anesthetized with benzocaine $(2 \%$ in water) and sacrificed through spinal section. Morphometric data (sex, total length, total body and liver weight) was annotated and the liver and bile collected. Liver samples were immediately frozen in liquid nitrogen and stored at $-80^{\circ} \mathrm{C}$ for biochemical analyses. All biliary content was collect using a sterile syringe and stored at $-20^{\circ} \mathrm{C}$ for subsequent analyses.

Somatic indexes were calculated according with Vazoller (1996) and Lombardi et al. (2010). Hepatic somatic index (HSI) was calculated as HSI $=$ [liver weight $(\mathrm{g}) /$ body weight] ${ }^{*} 100$ and Condition Factor (CF) was determinate as $\mathrm{CF}=[$ body weight $(\mathrm{g}) /$ length $\left.(\mathrm{cm})^{3}\right]^{*} 100$. The gonadal index (DK) was obtained by the expression: $\left(\mathrm{TW}^{\mathrm{T}} \mathrm{TL}^{\mathrm{b}}\right)-\left(\mathrm{BW} / \mathrm{TL}^{\mathrm{b}}\right)$, where:

$\mathrm{TW}=$ total weight $(\mathrm{g})$

$\mathrm{TL}=$ total length $(\mathrm{mm})$

$\mathrm{BW}=$ body weight $(\mathrm{g})$

$\mathrm{b}=$ angular coefficient of the allometric expression $\mathrm{Y}=$ $\mathrm{a} \cdot \mathrm{x}^{\mathrm{b}}$

Biochemical Analyses

The MFO system was measured in the microssomal fraction of the individual livers of $C$. spixi according with Livingstone (1988). Frozen livers $(\sim 1.00 \mathrm{~g})$ were homogenized in buffer containing $10 \mathrm{mM}$ Tris- $\mathrm{HCl}, 0.15 \mathrm{M} \mathrm{KCl}$ and $0.5 \mathrm{M}$ sucrose ( $\mathrm{pH} 7.6)$ and centrifuged three times: $500 \mathrm{~g}$ for $15 \mathrm{~min}, 12,000 \mathrm{~g}$ for $45 \mathrm{~min}$ and then at $100,000 \mathrm{~g}$ for $90 \mathrm{~min}$ ) Microssomal pellets were dissolved in $20 \mathrm{mM}$ Tris- $\mathrm{HCl}$ and $20 \%$ glycerol (pH 7.6). The microsomal suspension of each sample were immediately used for the analysis. All assays were carried out in triplicate. Total cytochrome P450 and the '418-peak' (putative denatured cytochrome P450) contents were evaluated by the carbon monoxide difference spectrum of the sodium dithionite reduced sample, and absorbance values were measured in the interval $400-500 \mathrm{~nm}$, using an extinction coefficient of $91 \mathrm{mM}^{-1} \mathrm{~cm}^{-1}$. Cytochrome $b_{5}$ content was determined by the differences in spectra of microsomes reduced with 6 $\mathrm{mM}$ NADH versus oxidized microsomes using an extinction coefficient of $185 \mathrm{mM}^{-1} \mathrm{~cm}^{-1}$ by the differences in absorbance values measured at 409 and $425 \mathrm{~nm}$ (ESTABROOK; WERRINGLOER, 1978).

NAD(P)H cytochrome $c$ reductase activity was calculated by the increase in absorbance values measured at $550 \mathrm{~nm}$ after addition of $0.3 \mathrm{mM} \mathrm{NADPH}$ using an extension coefficient of $19.6 \mathrm{mM}^{-1} \mathrm{~cm}^{-1}$. Total microsomal protein concentrations were measured according to Lowry et al. (1951) using bovine serum albumin (BSA) as a standard.

Fish bile Fluorescent Aromatic Compounds (FACs)

Concentrations of PAH metabolites in bile content were determined according to Yang and Baumann (2006) with modifications. Bile samples were first diluted in $48 \%$ methanol $(1: 1500$ bile/methanol) and the metabolites determined according with the sets of emission and excitation wavelengths in fluorimeter reader (spectrofluorimeter RF-5301 PC): 2-rings PAH compounds, $(288 \mathrm{~nm} / 330$ $\mathrm{nm}$, naphthalene type), 3-rings PAH compounds (267 $\mathrm{nm} / 309 \mathrm{~nm}$, phenanthrene type), 4-rings (334 nm/376 $\mathrm{nm}$, pyrene type, 5-rings (364 nm/406 nm, benzo(a)pyrene type $)$ and 6-rings $(380 \mathrm{~nm} / 422 \mathrm{~nm}$, benzo(gli)perylene type). The results were normalized to biliary concentration in $n g \mu \mathrm{L}^{-1}$. Samples of $100 \mu \mathrm{g}$ $\mathrm{mL}^{-1} 16$ USEPA PAHs diluted in $48 \%$ methanol $(1: 1000,1: 1500,1: 2000,1: 3000,1: 4000,1: 5000$, $1: 10000)$ were used as standards.

Statistical Analysis

Normality of data was assessed by Kolmogorov-Smirnoff test and differences between sites in the biological parameters, variability of PAH concentrations and MFO levels were tested by ANOVA analysis. Tukey's test was performed to compare differences between groups with somatic indices and MFO compound contents. Differences among metabolites of PAHs were assessed using Posthoc Bonferroni test. Results were represented as mean \pm standard deviation for all tests statistically significance were considered at $p \leq 0.05$.

\section{RESULTS}

Biological Aspects

All C. spixii sampled were mature individual, with active gonadal maturation, including spawning and post-spawning. Data about biological aspects of $C$. spixii from the non-polluted estuary (Cananéia) and from three sites within Santos-São Vicente estuary (SC, SVC and SB) are shown in the Table 2. In order to verify the influence of the gender, all biological data and somatic indexes were first evaluated in separate male and female groups. Sexdependent differences were not found for length, weight, HSI and CF analyses, therefore for these analyses animals were separated only by respective sampling site group. Based on weight data, fish from SB site collected in winter showed weight values significantly lower $(37 \pm 22 \mathrm{~g})$ than fish sampled in the same period in SB $(213 \pm 78 \mathrm{~g})$. Meanwhile, fish from 
Can and SVC showed weight values significantly lower $(p<0.05)$ in the summer (Can: $45 \pm 19 \mathrm{~g}$; SVC: $57 \pm 23 \mathrm{~g}$ ) compared to fish collected in winter (Can: $83 \pm 78 \mathrm{~g}$; SVC: $75 \pm 23 \mathrm{~g}$ ). According with length values obtained, there are no significant differences between fish sampled in the both estuaries.

Based on HSI analyses, the lowest values were observed in individuals from Can $(1.50 \pm 0.32)$ and the highest values were obtained in specimens from SC $(2.07 \pm 0.28)$. However, statically differences were not observed neither between sampling sites nor seasonality. Based on CF values, only fish from SC collected in the summer showed significant differences in relation to reference site. According with the DK analysis, only males from SB sampled in the winter $\left(\mathrm{DK}_{\mathrm{M}}=64.7 \%\right)$ showed significant differences in relation to reference animals. In general all females showed a displacement reservation for the reproduction of $9-13 \%$ (Table 2) while for males 10 $15 \%$, except for fishes from BS collected in winter (DK: 64.7\%).

\section{MFO system}

Data concern hepatic MFO levels in C. spixii are shown in Figure 2. In general, significant differences were found in levels of CYP450, $b_{5}$, NADH and NADPH. Fish from SC showed a similar pattern than fishes from SB meanwhile fishes from SVC showed similar MFO levels then individuals from reference site (Can) (Fig. 2).
The activity of total CYP450 in fish from SC and SB was higher than those from Can site. Lower total CYP450 levels (similar to that of Can site), were observed in fish from SVC. Although the pattern of cytochrome $b_{5}$ activity and CYP450 was similar, the activity of cytochrome $b_{5}$ was high in this species. In addition, significant seasonal differences were found in total CYP450 and $b_{5}$ activities in fish from SB sampled in the summer. High levels of total CYP450 and $b_{5}$ activities were observed in fishes from SC collected in the winter. Moreover, no significant variations were detected in CYP450 and $b_{5}$ activities in fish from SVC and Can site. Significant seasonal differences were observed in the NADPH and NADH contents of specimens from SB collected in the summer, when higher values were detected compared to winter.

\section{Fluorescent Aromatic Compounds (FACs) in Bile}

Figure 3 shows the mean levels of the $\sum \mathrm{PAH}$ in bile extract of $C$. spixii from all studied sites. $\sum \mathrm{PAH}$ content was statically higher $(p<0.05$ Bonferroni posthoc test) in fish from SC and SVC than in $C$. spixii from Can site and SB. However, there were no differences in $\sum \mathrm{PAH}$ of fish from Can site $\left(67.81 \pm 4.51 \mathrm{ng} \mathrm{mL} \mathrm{m}^{-1}\right)$ compared to fishes from SB $\left(62.00 \pm 7.2 \mathrm{ng} \mathrm{mL}^{-1}\right)$ and between individuals from SC $\left(112.8 \pm 7.4 \mathrm{ng} \mathrm{mL}^{-1}\right)$ and $\operatorname{SVC}\left(99.39 \pm 10.12 \mathrm{ng} \mathrm{mL}^{-1}\right)$.
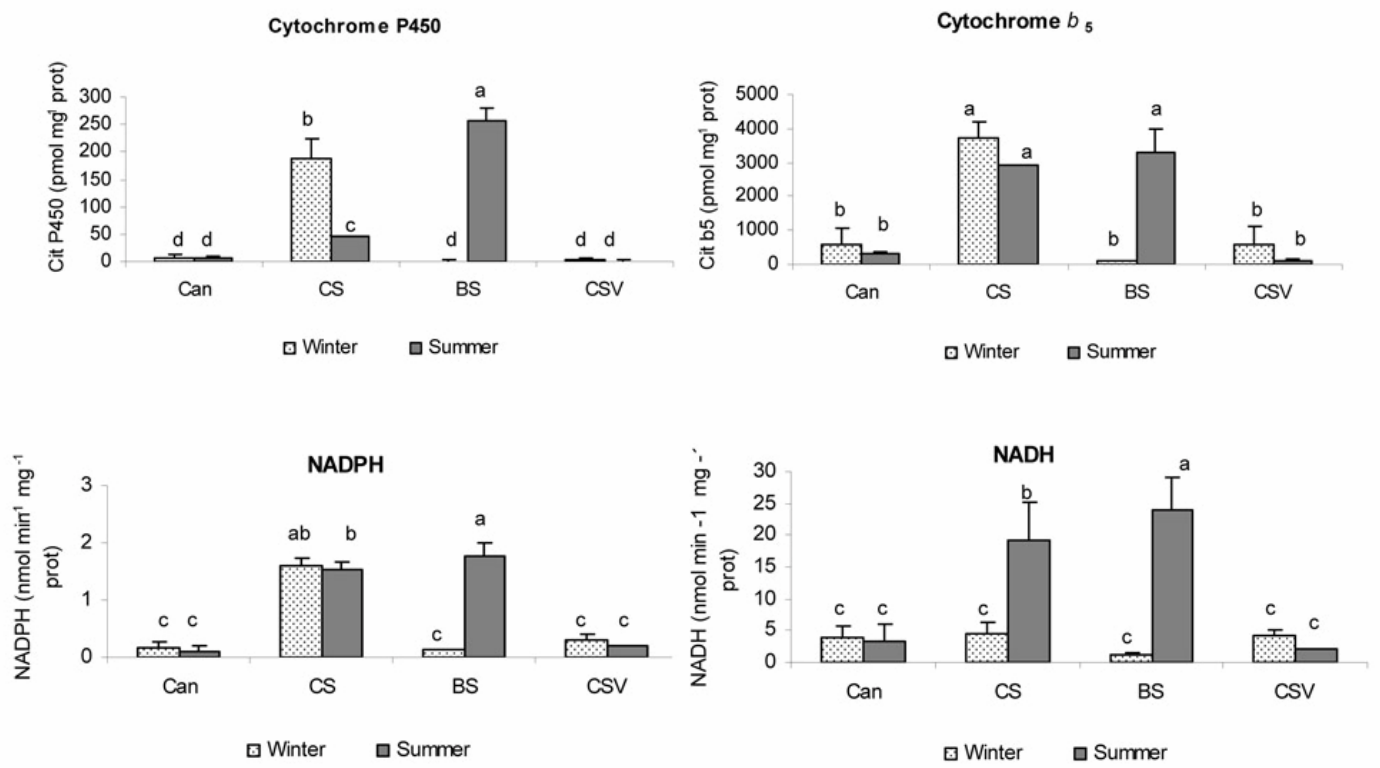

Fig. 2. Seasonal variation of monooxigenase (MFO) system for microsomal liver of C. spixii from Cananéia (Can) and three areas within the Santos-São Vicente estuary (SC: Santos channel; SB: Santos Bay; SVC: São Vicente channel). Data represent mean \pm sdv, and the bars followed by different letters are statistically different by Tukey post hoc test $(p<0.05)$. 


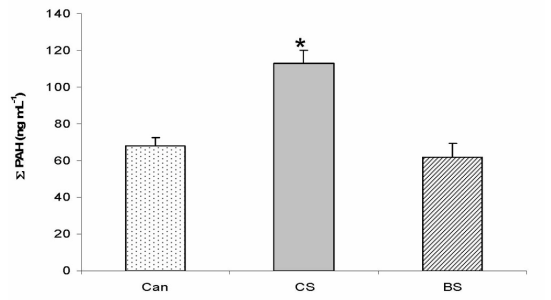

Fig. 3. Mean values \pm standard deviation of $\sum \mathrm{PAH}$ contents in bile of $C$. spixii from Cananéia estuary and three areas within Santos-São Vicente estuary (Santos channel: SC, Santos Bay: $\mathrm{SB}$, and São Vicente channel: SVC). Distinct letters indicatesignificant differences by Bonferroni test $(p<0.05)$.

The concentrations of PAH metabolites, expressed according with the number of aromatic rings, are shown in the Table 3. Animals from different sites shown different profiles of aromatic metabolites. Naphatalene-like PAHs were the major $\mathrm{PAH}$ group in fish bile of all sites (except in SVC) and the highest contents were found in $C$. spixii from SC (40.92 $\mathrm{ng} \mathrm{mL}^{-1}$ ). 3-ring PAHs were also predominant in fish from SC $\left(23.99 \mathrm{ng} \mathrm{mL}^{-1}\right)$. On the other hand, 4, 5- and 6- rings-PAHs were higher in individuals from SVC (39.10 $\mathrm{ng} \mathrm{mL}^{-1}, 22.72 \mathrm{ng} \mathrm{mL}^{-1}$ and $8.88 \mathrm{ng} \mathrm{mL}^{-1}$, respectively). Significant differences were found in the levels of 4, 5- and 6-rings PAH comparing individuals from the polluted areas in relation to reference site. Individuals from polluted areas showed higher concentrations of high molecular weight PAHs like benzo(a)pyrene-like (5 rings) (14\% content) and benzo(ghi)perilene-like (6 rings) (15\% content) then from the reference site ( $7 \%$ and $4 \%$ respectively).

\section{Discussion}

In order to characterize sampling sites studies analytical chemistry assays of water were performed (Table 1) at the same period of this study. Based on this results of analytical chemistry of water (nutrients, $\mathrm{pH}$ and dissolved oxygen) Can site shown characteristics of a low human influence. On the other hand, Santos-São Vicente estuary sites showed high values of nutrients, indicating anthropogenic influence. Levels of dissolved oxygen (DO) are also in accordance with this argument. Details about water chemistry to both estuaries can be obtained in Azevedo et al. (2009a).

The use of somatic indexes such as HSI, CF, and $\Delta \mathrm{K}$ in environmental studies were considered useful tools to evaluate the influence of biotic factors in the accumulation of these types of contaminants (ADAMS; RYON, 1994; KARELS et al., 1998; COUILLARD et al., 1999; LOMBARDI et al., 2010). Azevedo et al. (2009a) observed high HSI values in $C$. spixii from polluted sites in Santos-São Vicente estuary as compared with fish from a reference unpolluted area. However, in the present study no significant differences were observed between HSI of fish from Santos-São Vicente and those from the Cananéia estuary. This finding can be explained by sampling period, different abiotic influences and, more specifically, by the high levels of individual variations in HSI. Excepting fish from SC sampled in the summer, $\mathrm{CF}$ observed in $C$. spixii can be to indicating an absence of negative effects, or an adaptive response to the presence of miscellaneous chemicals in the Santos-São Vicente estuary. DK was also considered, as well as GSI index, to investigate the variation in gonadal maturation stages among the specimens studied. In general, no significant differences were observed in DK values of $C$. spixii from both estuaries. The similarity in gonad conditions between individuals could be an inner characteristic of the species. However, the highest DK values observed in males compared with females can be related to the male catfish role in the incubation of the fecundated oocytes (VAZZOLER et al., 1989; VAZZOLER 1996), so needing for it larger displacement reserves for the reproduction.

The present work integrated the levels of P450 enzymes with the PAH metabolites in bile and the ecological indexes to evaluate the impact of human activities on studied sites. Exposure to PAHs induces the total CYP450 activities especially the CYP1A family (LEE; ANDERSON, 2005). A strong induction of the total CYP450 was observed in fish exposed to 4-6-rings PAHs as benzo(a)pyrene (SAUER et al., 1993; BURNS et al., 1997; AAS et al., 2000; LEE; ANDERSON, 2005). Therefore, the family CYP450 has been largely used as a specific biomarker of PAHs exposure (SCHLENK et al., 1993; AL-ARABI; GOKSOYR, 2002) and the present results in this species support this statement.

The obtained data showed high levels of total CYP450 in individuals from SC and SB compared to individuals from SVC and Can site. These findings are in accordance with that described by other tropical fish species from south and southeast coast of Brazil (Table 4). The high levels of $b_{5}$ found in $C$. spixii are probably associated with the intraspecific endogenous processes, once this enzyme $\left(b_{5}\right)$ is primarily involved in the oxidation of various endogenous substrates and acts as an electron transfer component in a number of oxidative reactions (SCHENKMAN; JANSSON 2003). The present data is in accordance with other studies where high levels of total CYP450 and $b_{5}$ were also found in fish species from North Sea exposed to organic compounds (MEHRTENS; LATURNUS 1999). Tagliari et al. (2004) also reported high levels of total CYP450 and $b_{5}$ in the liver of G. gymnogenys from a polluted site in São Paulo State. These authors suggest that these increased levels are an evidence of peroxidative lesions mediated by free radicals. 
Table 1. Seasonal water chemistry data from Cananéia estuary (Can) and in three sites within Santos-São Vicente estuary (SC: Santos channel; SB: Santos Bay; SVC: São Vicente channel). Data represent mean, maximum and minimum in parenthesis. Adapted from Azevedo et al (2009a).

\begin{tabular}{|c|c|c|c|c|c|c|}
\hline Region & pH & DO & P-PO ${ }_{4}{ }^{-3}$ & $\mathrm{~N}-\mathrm{NO}_{3}{ }^{-}$ & $\mathrm{N}-\mathrm{NO}_{2}{ }^{-}$ & $\overline{\mathrm{N}-\mathrm{NH}_{4}{ }^{+}}$ \\
\hline \multicolumn{7}{|l|}{ Winter } \\
\hline Can & $\begin{array}{l}7.84 \\
(7.54-8.10)\end{array}$ & $\begin{array}{l}4.76 \\
(4.42-4.98)\end{array}$ & $\begin{array}{l}1.30 \\
(0.77-1.94)\end{array}$ & $\begin{array}{l}0.19 \\
(0.14-0.29)\end{array}$ & $\begin{array}{l}0.93 \\
(0.56-1.83)\end{array}$ & $\begin{array}{l}2.73 \\
(2.25-3.67)\end{array}$ \\
\hline SC & $\begin{array}{l}7.92 \\
(7.80-8.08)\end{array}$ & $\begin{array}{l}3.61 \\
(3.12-4.39)\end{array}$ & $\begin{array}{l}4.48 \\
(1.87-7.01)\end{array}$ & $\begin{array}{l}0.93 \\
(0.11-1.97)\end{array}$ & $\begin{array}{l}4.22 \\
(0.58-8.85)\end{array}$ & $\begin{array}{l}10.47 \\
(6.16-14.54)\end{array}$ \\
\hline SB & $\begin{array}{l}8.22 \\
(8.16-8.25)\end{array}$ & $\begin{array}{l}4.15 \\
(3.88-4.71)\end{array}$ & $\begin{array}{l}1.25 \\
(0.55-3.10)\end{array}$ & $\begin{array}{l}0.09 \\
(0.03-0.14)\end{array}$ & $\begin{array}{l}0.20 \\
(0.03-0.58)\end{array}$ & $\begin{array}{l}3.30 \\
(1.62-2.92)\end{array}$ \\
\hline SVC & $\begin{array}{l}7.55 \\
(7.48-7.65)\end{array}$ & $\begin{array}{l}3.18 \\
(3.01-3.36)\end{array}$ & $\begin{array}{l}6.26 \\
(5.13-7.87)\end{array}$ & $\begin{array}{l}0.35 \\
(0.31-0.41)\end{array}$ & $\begin{array}{l}1.36 \\
(0.96-1.48)\end{array}$ & $\begin{array}{l}23.20 \\
(20.55-24.86)\end{array}$ \\
\hline \multicolumn{7}{|c|}{ Summer } \\
\hline Can & $\begin{array}{l}7.83 \\
(7.50-8.09)\end{array}$ & $\begin{array}{l}3.82 \\
(3.35-4.01)\end{array}$ & $\begin{array}{l}1.77 \\
(1.10-2.70)\end{array}$ & $\begin{array}{l}0.17 \\
(0.07-0.35)\end{array}$ & $\begin{array}{l}0.11 \\
(0.09-0.17)\end{array}$ & $\begin{array}{l}1.38 \\
(0.79-2.12)\end{array}$ \\
\hline SC & $\begin{array}{l}8.01 \\
(7.78-8.41)\end{array}$ & $\begin{array}{l}2.73 \\
(1.67-4.75)\end{array}$ & $\begin{array}{l}5.37 \\
(1.15-8.30)\end{array}$ & $\begin{array}{l}21.81 \\
(1.13-31.69)\end{array}$ & $\begin{array}{l}4.44 \\
(0.25-8.13)\end{array}$ & $\begin{array}{l}14.42 \\
(2.10-24.52)\end{array}$ \\
\hline SB & $\begin{array}{l}8.31 \\
(8.22-8.39)\end{array}$ & $\begin{array}{l}3.95 \\
(3.29-4.45)\end{array}$ & $\begin{array}{l}1.12 \\
(0.83-1.74)\end{array}$ & $\begin{array}{l}5.47 \\
(3.80-6.45)\end{array}$ & $\begin{array}{l}1.38 \\
(0.63-2.63)\end{array}$ & $\begin{array}{l}4.93 \\
(0.32-14.06)\end{array}$ \\
\hline SVC & $\begin{array}{l}7.39 \\
(7.21-7.63)\end{array}$ & $\begin{array}{l}1.31 \\
(1.09-1.62)\end{array}$ & $\begin{array}{l}5.09 \\
(4.18-5.89)\end{array}$ & $\begin{array}{l}7.52 \\
(5.30-9.95)\end{array}$ & $\begin{array}{l}3.19 \\
(2.16-4.25)\end{array}$ & $\begin{array}{l}38.67 \\
(39.08-44.00)\end{array}$ \\
\hline
\end{tabular}

DO: dissolved oxygen $\left(\mathrm{mg} \mathrm{L}^{-1}\right), \mathrm{P}_{-} \mathrm{PO}_{4}^{-3}$ :inorganic dissolved phosphorus, $\mathrm{N}-\mathrm{NO}_{3}{ }^{-}$: nitrate, $\mathrm{N}^{-\mathrm{NO}_{2}}{ }^{-}$: nitrite, and $\mathrm{N}-\mathrm{NH}_{4}^{+}$: ammonium. Nutrients in $\mu \mathrm{M}$.

Table 2. Total length (TL), total weight (TW), hepatic somatic index (HSI) and condition factor (CF) of Cathorops spixii from Cananéia estuary (Can) and three areas within the Santos-São Vicente estuary (SB: Santos Bay, SC: Santos channel and SVC: São Vicente channel). Data represent mean \pm standard deviation. $n=18$ (Can), 10 (SB), 10 (SC) and 10 (SVC) fish for sampling period.

\begin{tabular}{lllllll}
\hline \hline \multicolumn{2}{l}{ TL (mm) } & TW (g) & HSI & CF & $\% \mathrm{DK}_{\mathrm{F}}$ & $\% \mathrm{DK}_{\mathrm{M}}$ \\
\hline Winter & & & & & \\
\hline Can & $192 \pm 48^{\mathrm{a}}$ & $83 \pm 78^{\mathrm{b}}$ & $1.76 \pm 0.23^{\mathrm{d}}$ & $0.96 \pm 0.09^{\mathrm{d}}$ & 11.9 & 11.3 \\
SC & $239 \pm 35^{\mathrm{a}}$ & $138 \pm 97^{\mathrm{ab}}$ & $2.07 \pm 0.28^{\mathrm{d}}$ & $0.91 \pm 0.12^{\mathrm{d}}$ & 11.6 & 64.7 \\
SB & $149 \pm 28^{\mathrm{a}}$ & $37 \pm 22^{\mathrm{c}}$ & $2.03 \pm 0.52^{\mathrm{d}}$ & $1.04 \pm 0.13^{\mathrm{d}}$ & 12.4 & 10.9 \\
SVC & $195 \pm 20^{\mathrm{a}}$ & $75 \pm 23^{\mathrm{b}}$ & $1.66 \pm 0.16^{\mathrm{d}}$ & $0.99 \pm 0.06^{\mathrm{d}}$ & 12.3 & 11.4 \\
\hline Summer & & & & & \\
\hline Can & $166 \pm 22^{\mathrm{a}}$ & $45 \pm 19^{\mathrm{c}}$ & $1.50 \pm 0.32^{\mathrm{d}}$ & $0.92 \pm 0.05^{\mathrm{d}}$ & 13.2 & 15.0 \\
SC & $226 \pm 34^{\mathrm{a}}$ & $109 \pm 54^{\mathrm{ab}}$ & $2.02 \pm 0.38^{\mathrm{d}}$ & $0.83 \pm 0.08^{\mathrm{e}}$ & 12.6 & 12.3 \\
SB & $284 \pm 29^{\mathrm{a}}$ & $213 \pm 78^{\mathrm{ab}}$ & $1.83 \pm 0.50^{\mathrm{d}}$ & $0.91 \pm 0.09^{\mathrm{d}}$ & 9.7 & 12.5 \\
SVC & $182 \pm 28^{\mathrm{a}}$ & $57 \pm 23^{\mathrm{c}}$ & $1.69 \pm 0.38^{\mathrm{d}}$ & $0.91 \pm 0.08^{\mathrm{d}}$ & 11.4 & 10.2 \\
\hline
\end{tabular}

Distinct letters indicate significant differences by Tukey test $(p<0.05) . \% \mathrm{DK}_{\mathrm{F}}=$ gonadal index of females; \% $\mathrm{DK}_{\mathrm{M}}=$ gonadal index of males

Table 3. Total amounts of PAH metabolites $\left(\mathrm{ng} \mathrm{mL}^{-1}\right)$ expressed as aromatic ring numbers in C. spixii from Cananéia estuary (Can) and within three areas in the Santos-São Vicente estuary (SC: Santos channel; SB: Santos Bay; and SVC: São Vicente channel).Data are expressed as mean and range (max-mix).

\begin{tabular}{ccccccc}
\hline \hline Site & 2 rings & 3 rings & 4 rings & 5 rings & 6 rings & $\sum$ PAH \\
\hline Can & 33.62 & 19.69 & 6.79 & 4.90 & 2.81 & 67.80 \\
& $(19.25-57.57)$ & $(15.58-34.77)$ & $(5.82-9.52)$ & $(3.53-8.80)$ & $(1.85-4.40)$ & $(42.95-98.28)$ \\
SB & 26.23 & 12.15 & 12.38 & 8.52 & 2.86 & 62.14 \\
& $(17.39-41.22)$ & $(8.11-17.72)$ & $(8.54-14.89)$ & $(4.85-10.79)$ & $(1.75-3.91)$ & $(56.93-74.92)$ \\
SC & 40.92 & 23.99 & 29.44 & 12.53 & 5.95 & 112.82 \\
& $(33.29-46.34)$ & $(18.44-30.63)$ & $(6.29-66.16)$ & $(6.37-25.12)$ & $(3.37-10.47)$ & $(93.00-169.17)$ \\
SVC & 18.94 & 9.73 & 39.10 & 22.72 & 8.88 & 99.38 \\
& $(17.85-55.78)$ & $(8.68-10.78)$ & $(24.95-53.26)$ & $(11.10-34.34)$ & $(5.07-12.69)$ & $(71.95-126.82)$ \\
\hline
\end{tabular}


Table 4. Levels of the MFO system in fish liver microsomes from reference $\left.{ }^{*}\right)$ and polluted sites. Data are mean \pm standard deviation..Cytochrome P450 and $b_{5}\left(\mathrm{pmol} \mathrm{mg} \mathrm{prot}{ }^{-1}\right)$ and NADPH cytochrome $c$ reductase $\left(\mathrm{nmol} \mathrm{min}^{-1} \mathrm{mg}\right.$ $\left.\operatorname{prot}^{-1}\right)$.

\begin{tabular}{|c|c|c|c|c|c|c|}
\hline Specie & Localization & $\mathrm{n}$ & P450 & $b_{5}$ & NADPH & Reference \\
\hline $\begin{array}{l}\text { Gymnogeophagus } \\
\text { gymnogenys }\end{array}$ & $\begin{array}{l}\text { Rio Grande do Sul State, } \\
\text { Brazil * }\end{array}$ & 41 & $220 \pm 56$ & $320 \pm 27$ & ---- & Tagliari et al., 2004 \\
\hline $\begin{array}{l}\text { Gymnogeophagus } \\
\text { gymnogenys }\end{array}$ & $\begin{array}{l}\text { Rio Grande do Sul State, } \\
\text { Brazil }\end{array}$ & 60 & n.d. & $170 \pm 80$ & ---- & Tagliari et al., 2004 \\
\hline Oreochromis niloticus & São Paulo State, Brazil * & 34 & $170 \pm 140$ & $60 \pm 33$ & $120 \pm 50$ & Thomaz et al., 2004 \\
\hline Brycon cephalus & São Paulo State, Brazil * & 06 & $170 \pm 70$ & $120 \pm 70$ & $120 \pm 80$ & Thomaz et al., 2004 \\
\hline Brycon cephalus & São Paulo State, Brazil & 05 & $230 \pm 130$ & $100 \pm 10$ & $380 \pm 150$ & Leitão et al,, 2000 \\
\hline $\begin{array}{l}\text { Colossoma } \\
\text { macropomon }\end{array}$ & São Paulo State, Brazil & 09 & $310 \pm 190$ & $250 \pm 75$ & $420 \pm 190$ & Leitão et al,, 2000 \\
\hline Oreochromis niloticus & São Paulo State, Brazil & 06 & $160 \pm 90$ & $60 \pm 25$ & $290 \pm 130$ & Leitão et al,, 2000 \\
\hline Oreochromis niloticus & $\begin{array}{l}\text { Billings, São Paulo State, } \\
\text { Brazil }\end{array}$ & 07 & $810 \pm 220$ & $200 \pm 60$ & ----- & Bainy et al., 1999 \\
\hline Pleuronectes platessa & North Sea, German & 02 & $520 \pm 170$ & $100 \pm 20$ & --- & $\begin{array}{c}\text { Mehrtens and Laturnus } \\
1999\end{array}$ \\
\hline Limanda limanda & North Sea, German & 25 & $340 \pm 300$ & $160 \pm 110$ & ----- & $\begin{array}{c}\text { Mehrtens and Laturnus } \\
1999\end{array}$ \\
\hline Gadus morhua & North Sea, German & 03 & $220 \pm 30$ & $60 \pm 40$ & ----- & $\begin{array}{c}\text { Mehrtens and Laturnus } \\
1999\end{array}$ \\
\hline Cathorops spixii & São Paulo State, Brazil * & 18 & $7 \pm 4$ & $488 \pm 337$ & $0.2 \pm 0.08$ & This work \\
\hline Cathorops spixii & São Paulo State, Brazil & 27 & $80 \pm 46$ & $2208 \pm 1650$ & $0.90 \pm 0.70$ & This work \\
\hline
\end{tabular}

In addition, the variation of NADH cit. $b_{5}$ reductase in general followed the same pattern of Cytochrome $b_{5}$ in fish from SC and SB (high levels), and in fish from SVC and Can site (low levels) following the profile of the total CYP450. These findings suggest the influence of the flavoprotein $\mathrm{NADH}$ cit. $b_{5}$ reductase in the cytochrome $b_{5}$ activities. NADPH cytochrome $\mathrm{c}$ reductase also showed the same pattern of total CYP450. This cofactor is an electron donor to CYP450 and changes is probably affecting the function of the monooxygenase system. The lower levels of CYP450 in individuals from SVC are explained in part by the presence of a large mangrove area. This type of ecosystem plays an important role in the immobilization of the contaminants in the sediments or in the biotransformation of organic pollutants due to the intense biological activity (BIANCHI, 2007).

Seasonality effects found in total CYP450, $b_{5}, \mathrm{NADPH}$ and/or NADH of fish from SC and/or SB reinforces the influence of organic contaminants in this system. In special in the summer period, fish from SB showed high levels of all CYP450 analyzed components. The summer period in this region is characterized by a heavy rainy season. Thus, the large rainfall in this period influences the input of contaminants or can also act by diluting these compounds. Finally, the present data supports the influence of organic compounds in Santos-São Vicente estuarine system as a potential risk to the biota.

FACs analysis in fish bile content confirmed a high anthropogenic influence in Santos-São Vicente estuary in comparison with Cananéia. The data presented in this work showed the effect of contaminants on the expression of CYP450. The present work reinforce the use of these enzymatic systems as an efficient tool to assess environmental impacts in field studies. Finally, the use of biomarkers associated with somatic indexes and chemical analyses are essential to understand anthropogenic impacts and generate a more effective diagnosis of environmental health effects.

\section{ACKNOWLEDGMENTS}

This work was supported by CAPES (Brazilian Agency for Science and Technology), Oceanographic Institute of São Paulo University and the Laboratory of Ecotoxicology and Environmental Chemistry of the University of Algarve. Azevedo J. S. was a recipient of fellowships from CAPES-PDEE (BEX 2176/07-6) and this study make a part of the FAPESP Project MOBIO, Process number 2005/50769-2.

\section{REFERENCES}

AAS, E.; BAUSSANT, T.; BALK, L.; LIEWENBORG, B.; ANDERSEN, O. K. PAH metabolites in bile, cytochrome P4501A and DNA adducts as environmental risk parameters for chronic oil exposure: a laboratory experiment with Atlantic cod. Aquatic Toxicol., v. 51, p. 241-258, 2000.

ADAMS, S. M.; RYON, M. G. A comparison of health assessment approaches for evaluating the effects of contaminant-related stress on fish populations. J. Aquatic Ecossyst. Health., v. 3, p. 15-25, 1994. 
AKAISHI, F. M.; ST-JEAN, S. D.; BISHAY, F.; CLARKE, J.; RABITTO, I. S.; OLIVEIRA RIBEIRO, C. A Immunological responses, histopathological finding and disease resistance of blue mussel (Mytilus edulis) exposed to treated and untreated municipal wastewater. Aquatic Toxicol., v. 82, n. 1, p. 1-14, 2007.

AL-ARABI, S. A. M.; GOKSOYR, A. Cytochrome P4501A responses in two tropical fish species, riverine catfish (Rita rita) and marine mudfish (Apocryptes bato). Comp. Biochem. Physiol., Part C, v. 131, p. 61-71, 2002

AZEVEDO, J. S.; FERNANDEZ, W. S.; FARIAS, L. A.; FÁVARO, D. T. I.; BRAGA, E. S. Use of the tropical brazilian fish Cathorops spixii as a bioindicator of trace metals pollution in Santos Bay. Ecotoxicol., v. 18, p. 577-586, 2009.

AZEVEDO, J. S.; SERAFIM A.; COMPANY, R.; BRAGA, E.; FÁVARO, D. I.; BEBIANNO, M.J. Biomarkers of exposure to metal contamination and lipid peroxidation in the benthic fish Cathorops spixii from two estuaries in South América, Brazil. Ecotoxicol., v. 18, p. 1001-1010, 2009a.

BAINY, A. C. D.; BRUCE R.; WOODIN, B. R.; STEGEMAN, J. J. Elevated levels of multiple cytochrome $\mathrm{P} 450$ forms in tilapia from Billings Reservoir-São Paulo, Brazil. Aquatic Toxicol., v. 44, p. 289-305, 1999.

BIANCHI, T. S. Biogeochemistry of Estuaries. Oxford: Oxford University Press, 2007. 706 p.

BOENING, D. W. Ecological effects, transport, and fate of mercury: a general review. Chemosphere, v. 40, p. 1335-1351, 2000.

BOON, J. P.; LEWIS,W. E.; CHOY, M. R.; ALLCHIN, C. R.; LAW, R. J.; de BOER, J. Levels of polybrominated diphenyl ether (PBDE) flame retardants in animals representing different trophic levels of the North Sea food web. Environt. Sci. Technol., v.36, p. 4025-4032, 2002.

BURNS, W. A.; MANKIEWICZ, P. J.; BENCE, A. E.; PAGE, D.S.; PARKER, K.R. A principal-component and least-squares method for allocating polycyclic aromatic hydrocarbons in sediment to multiple sources. Environ. Toxicol. Chem., v. 16, p. 1119-1131, 1997.

COUILLARD, C. M.; WILLIAMS, P. J.; COURTENAY, S. C.; RAWN, G. P. Histopatological evaluation of Atlantic Tomcod (Microgadus tomcod) collected at estuarine sites receiving pulp and paper mil effluent. Aquatic Toxicol., v. 44, p. $263-278,1999$.

ESTABROOK, R. W.; WERRINGLOER, J. The measurement of difference spectra: Application to the cytochromes of microsomes. Methods Enzymol., v. 52, p. 212-220, 1978.

FÁVARO, L.F.; FREHSE, F.A.; OLIVEIRA, R.N.; SCHWARZ JÚNIOR, R. Reprodução do bagre amarelo, Cathorops spixii (Agassiz) (Siluriformes, Ariidae), da Baía de Pinheiros, região estuarina do litoral do Paraná, Brasil. Rev. Bras. Zool., v. 22(4), p. 1022-1029, 2005.

FIGUEIREDO, J. L.; MENEZES, N. A. Manual de peixes marinhos do sudeste do Brasil. II. Teleostei (1). São Paulo: Museu de Zoologia da Universidade de São Paulo, 1978. 110 p.

FISK, A. T.; HOBSON, K. A.; NORSTROM, R. J. Influence of chemical and biological factors on trophic transfer of persistent organic pollutants in the Northwater Polynya marine food web. Environ. Sci. Technol., v. 35, p. 732738, 2001.

FU, G. H.; YANG, X. L.; ZHANG, H. X.; YU, W. J.; HU, K. Effects of cytochrome P450 1A substrate (difloxacin) on enzyme gene expression and pharmacokinetics in crucian carp (hybridized Prussian carp). Environ. Toxicol. Pharm., v. 31, p 307-313, 2011.

GOMES, I. D.; ARAÚJO, F. G.; AZEVEDO, M. C. C.; PESSANHA, A.L.M. Biologia reprodutiva dos bagres marinhos Genidens genidens (Valenciennes) e Cathorops spixii (Agassiz) Siluriformes, Ariidae), na Baía de Sepetiba, Rio de Janeiro, Brasil. Rev. Bras. Zool., v. 16, n. 2, p. 171-180, 1999.

GURGEL, H. C. B.; ALBUQUERQUE, C. Q.; SOUZA, D. S. L.; BARBIERI, G. Aspectos da biologia pesqueira em fêmeas de Cathorops spixii do estuário do rio Potengi, Natal/RN, com ênfase nos índices biométricos. Acta Scientiarum., v. 22, n. 2, p. 503-505, 2000.

HARTL, M. G. J.; KILEMADE, M.; SHEEHAN, D.; MOTHERSILL, C.; O'HALLORAN, J.; NORA M.; O'BRIEN, N. M.; VAN PELT, F. N. A. M. Hepatic biomarkers of sediment-associated pollution in juvenile turbot, Scophthalmus maximus L. Mar. Environ. Res., v. 64, p. 191-208, 2007.

HELLOU, J.; LEONARD, J.; COLLIER, T. K.; ARIESE, F. Assessing PAH exposure in feral fish from the Northwest Atlantic.Mar. Pollut. Bull., v. 52, p. 433441, 2006.

KARELS, A. E.; SOIMASUO, M.; LAPPIVAARA, J.; LEPPANEN, H.; AALTONEN, T.; MELLANEN, P.; OIKARI, A. O. J. Effects of EFC-bleached kraft mill effluent on reproductive steroids and liver MFO activity in populations of pearch and roach. Ecotoxicol., v. 7, p. 123-132, 1998

LEE, R. F.; ANDERSON, J. W. Signi.cance of cytochrome P450 system responses and levels of bile .uorescent aromatic compounds in marine wildlife following oil spills. Mar. Pollut. Bull., v. 50, p. 705-723, 2005.

LEITÃO, M. A. S.; AFFONSO, E. G.; SILVA, M. F. E.; MEIRELLES, N. C.; RANTIN, F. T.; VERCESI, A. E.; JUNQUEIRA, V.B.C.; DEGTEREV, I. A. The liver monooxygenase system of Brazilian freshwater fish. Comp. Biochem. Physiol., Part C, v. 126, p. 29-38, 2000.

LIVINGSTONE, D. R. Responses of microsomal NADPHcytochrome c reductase activity and cytochrome P450 in digestive glands of Mytilus edulis and Littorina littorea to environmental and experimental exposure to pollutants. Mar. Ecol Prog. Ser.,v. 46, p. 37-43, 1988.

LOMBARDI, P. E.; PERI, S. I.; GUERRERO, N. R. V. trace metal levels in Prochilodus lineatus collected from the La Plata River, Argentina. Environ. Monit. Assess., v. 160 , p. $47-59,2010$.

LOWRY, O. H.; ROSEBROUGH, N. J.; FARR, A. L; RANDALL, R.J. Protein measurement with Folin phenol reagent. J. Biol. Chem., v. 193, p. 265-275, 1951.

MAGALHÃES, C. A. PCBs e Pesticidas Organoclorados em tecidos de peixes da Baixada Santista, São Paulo. Dissertação de Mestrado. Universidade de São Paulo, Instituto Oceanográfico, 71 p, 2005.

MEHERTENS, G.; LATURNUS, F. Mixed function oxidase depent biotransformation of polychlorinated biphenyls by different species of fish from the North Sea. Chemosphere, v. 38, n. 13, p. 2995-3002, 1999. 
OLIVEIRA RIBEIRO, C. A.; VOLLAIRE, Y; SANCHEZ CHARDI, A.; ROCHE, H. Bioaccumulation and the effects of organochlorine pesticides, PAH and heavy metals in the Eel (Anguilla anguilla) at the Camargue Nature Reserve, France. Aquatic Toxicol., v. 74, p. 53 69, 2005.

SAUER, T. C.; BROWN, J. S.; BOEHM, P. D.; AURAND, D.V.; MICHEL, J.; HAYES, M.O. Hydrocarbon source identi.cation and weathering characterization of intertidal and subtidal sediments along the Saudi Arabian coast after the Gulf War oil spill. Mar. Pollut. Bull., v. 27, p. 117-134, 1993.

SCHLENK, D.; RONIS, M. J. J.; MIRANDA, C. L.; BUHLER, D. Channel catfish liver monooxygenases: Imminological characterization of constitutive cytochromes P450 and the absence of active flavincontaining monooxygenases. Biochem. Pharmacol., v. 45, 1, p. 217-221, 1993.

SCHENKMAN, J. B; JANSSON, I. The many roles of cytochrom b5. Pharmacol.Therap., v. 97, p. 139-152, 2003.

SERAFIM, A.; LOPES, B.; COMPANY, R.; FERREIRA, A.M.; BEBIANNO, M.J. Comparative petroleum hydrocarbons levels and biochemical responses in mussels from hydrothermal vents (Bathymodiolus azoricus) and coastal environments (Mytilus galloprovincialis). Mar. Pollut. Bull., ., v. 57, p. 529537, 2008.

STAGG, R. M.; RUSIN, J.; McPHAIL, M. E.; McINTOSH ,A.D.; MOFFAT, C.F.; CRAFT, J.A. Effects of polycyclic aromatic hydrocarbons on expression of CYP1A in salmon (Salmo sala) following experimental exposure and after the Braer oil spill. Environ.Toxicol.Chem., v. 19, p. 2797-2805, 2000.

TAGLIARI, K.C.; CECCHINI, R.; VAZ ROCHA, J.A.; VARGAS, V.M.F. Mutagenicity of sediment and biomarkers of oxidative stress in fish from aquatic environments under the influence of tanneries. Mutat. Res., v. 561, p. 101-117, 2004.

TIJARO, R.; RUEDA, M.; SSANTOS-MARTINEZ, A. Dinâmica poblacional del chivo mapalé Cathorops spixii em la Ciénaga Grande de Santa Marta y complejo de Pajarales, Caribe Colombiano. Boln. Invest. Mar. Cost., v. 27 , p. $87-102,1998$

THOMAZ A. A. R. S.; ROSSA, M. M.; RANTINA, F. T.; MATSUMURA-TUNDISI, T.; TUNDISI, J.G.; DEGTEREV, I.A. Comparison of liver mixed-function oxygenase and antioxidant enzymes in vertebrates. Comp. Biochem. Physiol., Part C, v. 137, p. 155-165, 2004.
VALDEZ DOMINGOS, F.X; AZEVEDO, M; SILVA, M.D.; RANDI, M. A. F.; FREIRE, C. A.; SILVA DE ASSIS, H.C.; OLIVEIRA RIBEIRO, C.A. Multibiomarker assessment of three Brazilian estuaries using oysters as bioindicators. Environ. Res., v. 105 , n. 3) p. 350-363, 2007.

VAZZOLER, A. E. A. de M.; CARACIOLO-MALTA, M. C.; AMADIO, S. A. Aspectos biológicos de peixes amazônicos. XII. Indicadores quantitativos do período de desova das espécies do gênero Semaprochilodus (Characiformes, Prochilodontidae) no baixo rio Negro, Amazonas, Brasil. Rev. Bras. Biol., v. 49, n. 1, p. 175$181,1989$.

VAZZOLER, A. E. A. de. Biologia da reprodução de peixes teleósteos: Teoria e Prática. Maringá, PR: EDUEM, 1996.

VUORINEN, P. J.; KEINÄNEN, M.; VUONTISJÄRVI, H.; BARSIENÉ, J.; BROEG, K.; FÖRLIN, L.; GERCKEN, J.; KOPECKA, J.; KÖHLER, A.; PARKKONEN, J.; PEMPKOWIAK, J.; SCHIEDEK, D. Use of biliary PAH metabolites as a biomarker of pollution in fish from the Baltic Sea. Mar. Pollut. Bull., v. 53, p. 479-487, 2006.

YANG, X.; BAUMANN, P. C. Biliary PAH metabolites and the hepatosomatic index of brown bullheads from Lake Erie tributaries. Ecol. Indic., v. 6, p. 567-574, 2006.

WHYTE, J. J.; JUNG, R. E.; SCHMITT, C. J.; TILLITT, D. E. Ethoxyresorufin- $O$-deethylase (EROD) activity in fish as a biomarker of chemical exposure. Crit. Rev. Toxicol., v. 30, p. 347-570, 2000.

ZIMMERMAN, M. Maturity and fecundity of arrowtooth flounder, Atheresthes stomias, from the Gulf of Alaska. Fish. Bull. v. 95, p. 598-611, 1997.
(Manuscript received 11 January 2011; revised 13 July 2011; accepted 20 November 2011) 